\title{
AZ INKLUZÍV NEVELÉS MA TANÁR SZAK A KODOLÁNYI JÁNOS FöISKOLÁN
}

\section{RÉTHY ENDRÉNÉ}

\author{
a Kodolányi János Főiskola \\ habilitált föiskolai tanára \\ tanszeknevtud@kodolanyi.hu
}

Az irás ismerteti a Kodolányi János Föiskolán folyó inkluzív nevelés tanára MA szak bevezetésének eddigi tapasztalatait. A képzés felépitését, hatékonyságát döntően a hallgatók hangjának tükrében, a hallgatók szemszögéböl mutatja be.

\section{A szakindítás előzményei}

Közel 50 éve folyik Magyarországon elméleti és gyakorlati szinten az integráció bevezetéséhez kapcsolódó elméleti és kísérleti próbálkozás. Ez alatt az időszak alatt meghatványozódtak nemzetközi szinten is az inkluzióhoz kapcsolódó kutatások és konkrét gyakorlati újítások.

Számos országra kiterjedő nemzetközi kutatási keretben szisztematikus formában 1997-ben indult magyarországi (Eötvös Loránd Tudományegyetem Neveléstudományi Intézet) részvétellel - az Európai Unió SOKRATES programjának támogatásával - az INTEGER projekt. A projekt 11 európai felsőoktatási intézmény oktatóinak bekapcsolódásával konzorciumban müködött. 2001-re a kutatómunka eredményeként elkészült egy tanártovábbképzési tervezet, tanárok és hallgatók számára összeállított tananyagfejlesztéssel együtt öt bázismodul, valamint 22 választható modul keretei között. E kutatómunkából fejlődött ki a 2001-től induló újabb Európai Uniós támogatással a SOCRATES ERASMUS, az inkluzió bevezetését célzó EUMIE (European Masters in Inclusive Education) projekt. ${ }^{1}$ A projektmunkálatokban hét ország felsőoktatási szakemberei vettek részt. A közös munka során elkészült egy moduláris rendszerü hálóterv curriculum, mely Európaszerte akkreditálható s megfelel a Bolognai Egyezmény követelményeinek.

Az integráció gyakorlatának elterjedésében nagy szerepet játszottak különbözö nemzetközi szervezetek, így az ENSZ, az UNESCO, az OECD és az EU. A hazai törvényalkotás is a megváltozott igényeknek megfelelően alkotta meg az integrációt támogató rendelkezéseit. A tanárképzéshez kapcsolódó kutatások terén szintén olvas-

${ }^{1}$ Magáról a projektről bővebb információ olvasható Réthy Endréné - Schaffhauser Franz - Schiffer Csilla, 2006. 
hatunk új fejleményekről, amelyek érintik az integrációt és inklúziót (Falus-Kotschy, 2006; Falus, 2010; Hunyady, 2010).

A fent vázoltakból következően is egyre sürgetőbb igényként merült fel az új tanári professzionalizmus jegyében a tanárképzés területén az integrációra, inklúzióra történő felkészítés. Az integráció, az inklúzió kérdése a gyakorló tanárok irányában a magas szintű szakmaiság és a kiterjesztett szerepelvárás keretei között fogalmazódott meg.

\section{Az inkluzív nevelés MA tanárszak indításáról a Kodolányi János Főiskolán}

A nemzetközi teamekben (INTEGER, EUMIE) szerzett tapasztalatokra támaszkodva, lehetővé vált, hogy megfontoltan és átgondoltan készüljön el a Kodolányi János Főiskola Inkluzív nevelés MA tanár szak akkreditációra benyújtott tervezete. ${ }^{2} \mathrm{Az}$ akkreditált képzés helye: Budapest, a Kodolányi János Főiskola Képzési Központja. Az első meghirdetett tanéve: 2009/2010. A képzési idő 3 félév. Kreditszám: 90. 180 kontakt óra +60 órás csoportos és egyéni szakmai gyakorlat.

A képzési cél: olyan pedagógusok képzése, akik elméleti, módszertani és gyakorlati tudásuk birtokában készek és képesek a különleges gondoskodásra jogosult gyermekek, tanulók befogadó nevelésére, differenciált, csoportos foglalkoztatására többségi keretek kötött, a többségi tanulókkal kooperálva. Együttmüködésre nyitottak a segítő szakmák képviselőivel és a szülőkkel.

A képzésbe bekerülés feltétele: egyetemi vagy föiskolai szintü tanári szakképzettség. Kiket vár a képzés?

- Akik szeretnék megfelelő felkészültséggel nevelni intézményükben a sajátos nevelési szükségletủ gyermekeket,

- akik humánus, gyermekbarát, elfogadó értékrenddel bírnak,

- akik fontosnak tartják, hogy minden gyermek megkapja a neki megfelelő minőségi nevelést-oktatást,

- akik szorgalmazzák az esélyhasonlóságot és a befogadás biztosítását,

- akik a nevelési-oktatási munka feladatait professzionális módon szeretnék ellátni és fontosnak tartják a tanár-diák kapcsolat javítását,

- akik új módszerekkel szeretnének megismerkedni a különböző képességekkel rendelkező tanulókkal való hatékonyabb foglalkozás céljából,

- akiknek az intézménye az SNI tanulók neveléséhez-oktatásához megfelelően felkészült pedagógusokkal akar rendelkezni.

A képzés szerkezete az alábbiak szerint épül fel: pedagógusi és pszichológiai elméleti és gyakorlati ismeretek (20 kredit); szakterületi ismeretek (40 kredit); kiegé-

\footnotetext{
${ }^{2}$ A 2007-ben benyújtott anyagot a Magyar Felsőoktatási Akkreditációs Bizottság 2008. 06. 25. MAB FVB 10/2008. számú határozata alapján az OM Oktatási Hivatal Határozata 2009. 04. 30-án elfogadta. (Nyilvántartásba vétel: OH-FHF/592-4/2009. sz. határozat jogerőre emelkedése)
} 
szítő szakterületi ismeretek (10 kredit); összefüggő csoportos és egyéni gyakorlat (20 kredit). A tantervről áttekintést ad az 1. táblázat.

\section{1. táblázat: Áttekintő tanterv}

\begin{tabular}{|c|c|c|c|c|c|c|}
\hline Óra & 1 félév & - & 2 & - & 3 & - \\
\hline 9 & $\begin{array}{l}\text { Az inkluzió } \\
\text { elméleti alapjai }\end{array}$ & 4 & $\begin{array}{l}\text { Alkalmazott } \\
\text { pszichológia } \\
\text { (Szociálpszichológia) }\end{array}$ & & $\begin{array}{l}\text { A sajátos nevelési } \\
\text { igény fejlödéslélektani } \\
\text { háttere k. gyak. }\end{array}$ & 4 \\
\hline 9 & $\begin{array}{l}\text { SNI gyerekek } \\
\text { pedagógiai } \\
\text { megismerése k. gyak. }\end{array}$ & 3 & $\begin{array}{l}\text { Tanulók és tanuló- } \\
\text { csoportok megismerése } \\
\text { k. gyak. }\end{array}$ & 3 & $\begin{array}{l}\text { Multikulturális és } \\
\text { interkulturális } \\
\text { nevelés k. gyak. }\end{array}$ & 3 \\
\hline 9 & $\begin{array}{l}\text { Az inkluzív nevelés } \\
\text { jogi szabályozói } \\
\text { k. gyak. }\end{array}$ & 4 & $\begin{array}{l}\text { Hazai és európai } \\
\text { tendenciák } \\
\text { az oktatásügyben }\end{array}$ & 3 & & \\
\hline 9 & $\begin{array}{l}\text { Az inklúzió elötörténete } \\
\text { k. gyak. }\end{array}$ & 3 & $\begin{array}{l}\text { A differenciális } \\
\text { pedagógia elmélete }\end{array}$ & 4 & & \\
\hline 9 & Inkluzív pedagógia & 3 & $\begin{array}{l}\text { Új oktatási módszerek } \\
\text { a gyakorlatban } \\
\text { k. gyak. }\end{array}$ & 3 & & \\
\hline 9 & $\begin{array}{l}\text { Roma gyerekek az } \\
\text { iskolában } \\
\text { k. gyak. }\end{array}$ & 3 & $\begin{array}{l}\text { Pedagógiai pszichológiai } \\
\text { esetmegbeszélés } \\
\text { k. gyak. }\end{array}$ & 3 & Összefüggő & 20 \\
\hline 9 & $\begin{array}{l}\text { Az inkluzív nevelés } \\
\text { társ.-i kontextusai }\end{array}$ & 3 & Fejlődésdiagnosztika & 3 & & \\
\hline 9 & $\begin{array}{l}\text { Konfliktus és elöítélet } \\
\text { kezelése a gyakorlatban } \\
\text { k. gyak. }\end{array}$ & 3 & $\begin{array}{l}\text { A sajátos nevelési igény } \\
\text { fejlődéslélektani háttere }\end{array}$ & 4 & & \\
\hline 9 & $\begin{array}{l}\text { Az inkluzív nevelés } \\
\text { hazai és nemzetk. gyak. }\end{array}$ & 3 & Csoportos szakmai & & & \\
\hline 9 & $\begin{array}{l}\text { Az inkluzív nevelés } \\
\text { módszertana k. gyak. }\end{array}$ & 3 & az inklúzióra) 60 óra & 4 & & \\
\hline Kredit & 32 & & 31 & & 27 & \\
\hline $\begin{array}{l}\text { Össz- } \\
\text { óraszám }\end{array}$ & 90 óra & & 72 óra +60 óra gyak. & & $\begin{array}{l}18 \text { óra + } 10 \text { hét } \\
\text { összefüggő gyak. }\end{array}$ & \\
\hline
\end{tabular}

Magyarázat: 洋edagógiai és pszichológiai elméleti és gyakorlati ismeretek: 20 kredit;

Szakterületi ismeretek: 40 kredit; İ-Kiegészítō szakterületi ismeretek: 10 kredit;"

Összefüggő egyéni szakmai gyakorlat: 20 kredit; A gyakorlati ismeretek kreditértéke: 59 kredit (66\%);

- : Kreditszámok oszlopa 
Az inkluzív nevelés tanára MA szakon oktató pedagógusok mindannyian minősítettek. A zárókövetelmények elérését a hallgató záróportfólió készítésével igazolja. A portfólió olyan hallgatói dokumentumgyüjtemény, amely megvilágítja a hallgató tanári kompetenciáit, illetve azok fejlődését, előre haladását és eredményeit, szem előtt tartva az integráció és az inklúzió sajátos szempontjait.

\section{A képzésben rész vett hallgatóság jellemzői}

Az MA képzésben részvevők különböző szintű diplomával (főiskolai, egyetemi) rendelkeznek. A képzés során ezért is kell alkalmazkodni, illetve építeni a hallgatók előzetes elméleti tudására, gyakorlati tapasztalataira, sajátos motivációira, valamint a képzéssel kapcsolatban megfogalmazott céljaikra, elvárásaikra. Csak így lehet elősegíteni azt a kognitív váltást, mely lehetővé teszi a zárt oktatási formák, a hagyományos oktatási módszerek helyett az új szervezeti formák, megoldások elsajátítását. Az elmélet és a gyakorlat közötti szoros kapcsolat beláttatása, felismertetése képzési célként jelentkezik. Csak az a tanár tudja az oktatásában magáévá tenni az új szemléletet, akit már a képzésben is hasonló hatás ért.

A Kodolányi János Főiskolán az MA inkluzív nevelés tanára szakon a képzés elindítása nagy kihívást jelentett 2009-ben. Egy új koncepció megvalósulásának feltételeit kellett kialakítani. Az egységes nézetrendszerre alapozott elméleti és gyakorlati képzés az eredményesség fontos feltétele volt. Az új képzéssel kapcsolatos kihívások közül a legfontosabbak a következök voltak:

- A bekerült hallgatóság életkori jellemzői: a korfa 40-50 év. ${ }^{3}$

- Valamennyien aktív pedagógusok rengeteg gyakorlati tapasztalattal és bizonytalansággal.

- Hitek, tévhitek sokasága.

- Elvárások a képzőhely felé: a gyakorlati munkához, a nevelés, oktatás hatékonyabbá tételéhez konkrét segítség.

A képzésre háruló fontos feladatok:

- a fogalmak tisztázása, azonos terminológia használata

- változtatás igényének kialakítása

- önismeret, önreflexió

- kutatás, fejlesztés igénye

- tudástranszfer

- a tanári kompetencia kialakulásának támogatása.

\footnotetext{
${ }^{3}$ Az ebből adódó problémákra lásd: Pléh, 2006.
} 
A képzéshez kapcsolódó innovatív törekvések. Alkalmazkodás a hallgatóság igényeihez

A megújulás alapjait azok a társadalomban végbemenő jelentős változások adják, amelyet a tudásalapú, innovatív társadalom igényeihez kapcsolhatók:

Feladat: a változó világ, a változó tudásigények kielégítése. Egyértelmúvé válik a közoktatási rendszer pedagógusigényeinek kiszolgálása. A felsőoktatást befolyásoló társadalmi és pedagógiai folyamatok egyensúlyba tartása is fontos érdek. Mindehhez hozzátartozhat az a társadalmi párbeszéd is, mely a tanári pálya presztízsének növelését segítené.

A tudás, tanulás újraértelmezése, ti. már nem az ismeretek hallgatók általi puszta befogadásáról van szó, hanem aktív, konstruktív, adaptív, önszabályozott tanúlásról, tudásról (Réthy, 2009). Fontos nézőpontváltásra van tehát szükség, a tananyagról a hallgatókra, annak aktív, kooperatív tanulására és a tanulás eredményességére kerül a hangsúly. Az oktatás tartalmához, a tananyaghoz kapcsolódóan a munka világának elvárásait is egyre komolyabban kell mérlegelni (Rapos, 2011).

A változó tanárszereppel is feltétlen számolni kell. Elkötelezett, innovatív, minden egyes diák számára optimális tanulási környezetet teremtő - nem csak az osztályteremben, a tanítási órákon, hanem azokon túl is -, különbözö területeken kompetens, felkészült, hatékony pedagógusokra van szükség az új kihívásoknak megfelelően. A személyre szabott tanulási módok, utak, formák előtérbe kerülése is fontos fejlemény a többségi és a sajátos nevelési igényü (SNI) gyermekek esetében is (Réthy, 2006, 2007).

A folyamatos szakmai fejlődés (önképzés, továbbképzés, átképzés), a reflektivitás, a módszertani megújulás új képzési gyakorlat keretei között oldható csak meg. A különböző szakemberek együttmüködése sajátos kooperációt, team-munkát, pedagógiai konzíliumot, kompetencia transzfert, együttmüködő versengést igényel (Réthy, 2007).

A kompetencia alapú tanárképzés a megújulás eszköze lehet, ti. az elméletigényes gyakorlati orientációjával a hídépítés szerepét töltheti be az „ünnepnapok” pedagógiája és a „hétköznapok” gyakorlata között. Az elmélet és gyakorlat harmóniáját jelenti mindez a képzésben.

A kutatásorientált tanárképzés elötérbe kerülése általános nemzetközi trend, ami igényli a hallgatók felkészítését a „saját” osztályban megtervezett, megszervezett $\mathrm{s}$ lefolytatott mikro-kísérletekre, mikro-vizsgálatokra, illetve a korszerü kutatás-módszertani tudással való felvértezésüket a képzés során.

\section{A gyakorlatra orientált strukturált képzés útja}

Az elmélet és a gyakorlat kérdései nem egymással ellentétes oldalakon szereplö konstruktumok, hanem egymással szoros kapcsolatban, interakcióban levők. Így az elméleti ismeretek közvetítése sem történhet a pedagógiai gyakorlat kikapcsolásával, 
de a gyakorlati tevékenység sem lehet eredményes a tudományos elméleti ismeretek felhasználása nélkül. Kitüntetett szerepet kapott a képzésben az elméleti ismeretek, tudástartalmak szakszerü, interdiszciplináris, a legfrissebb nemzetközi szakirodalomra, s annak komparatív megközelítésére épülö közvetítése (Réthy, 2009, 2011).

Az elméleti és a gyakorlati kérdések interakciója pedig egy nagyon termékeny egymásra hatást kell, hogy eredményezzen, nem csupán a gyakorlat keres hatékonyabb megoldásokat, hanem az elmélet is. Mindebböl következik a tudatos folyamatirányítás:

- az ismeretek hatékony közvetítése a hallgatók aktív részvételével;

- a tanári „eszközkészlet”gazdagítása: saját gyüjtésen alapuló feladatok, anyagok eszközök tárházának létrehozása, felhasználása;

- új differenciált szervezési formák, módszerek, eszközök elsajátítása a gyakorlatban is;

- felkészítés az osztályteremben végezhető kutatómunkára.

\section{A képzéshez kapcsolódó empirikus vizsgálatok, a hallgatók hangjának megismerése}

A Kodolányi János Főiskolán a 2009-től induló inkluzív nevelés tanára MA képzés hatékonnyá tétele érdekében vizsgálatokat folytattunk a hallgatóság körében közvetlenül a bekerüléskor: Motivációs kérdőív (Réthy, 2003), majd egy félév elteltével Flow kérdőív (Oláh, 2005), illetve a képzés legvégén Tanulási mintázat kérdőív (Vermunt, 1994; Gaskó és Kálmán, 2010) kiköltésére került sor. A következőkben e vizsgálat néhány eredményét mutatjuk be röviden.

A hallgatók nagy elvárással, belső motiváltsággal, konkrétan megfogalmazott célokkal léptek be az MA képzésbe. A bekerült, zömében 40-50 éves korosztály meglehetősen sok pedagógiai tapasztalattal, rutinnal rendelkezett, így a kognitív váltás sok esetben az ismeretek, tudás, nézetrendszer terén fokozott erőfeszítésbe került. Ennek támogatásában fontos szerepe volt a differenciált szervezési módok folyamatosan alkalmazásának.

A flow élmény nagyfokú megélése biztató lehet a képzés sikerességét illetően. A képzés során megélt erőfeszítés, kihívás, próbatétel megmozgatta a hallgatók teljes személyiségét, kognitív, affektív és effektív szféráját.

Fokozott szorongás a hallgatók egy-két százalékánál jelentkezett, ami nézetünk szerint a felnőttkori tanulás velejárójaként kezelendő, a megélt nagyobb tét, illetve a bokros teendők, a képzésen túli elfoglaltság „eredményeként”. Szerencsére az unalom, illetve az apátia megléte nem volt kimutatható a vizsgált hallgatóknál.

A kontaktórákon alkalmazott színes tevékenykedtetési repertoár elnyerte a hallgatóság tetszését, sikerrel és örömmel kapcsolódtak be a változatos tanulási formákba. Mód nyílt a kooperáció fontosságának saját „bőrön” történő elsajátítására. Elgondolkodtatóak az oktatógárda számára a hallgatók részéről felmerült nehézsé- 
gek, úgymint az előadásokon a reflektálás, a moodle felület kezelése és a vita módszere. Továbbiakban több lehetőséget, támogatást szükséges e téren is a hallgatók számára biztosítani.

A képzési eredmények egyértelmüen a kitüzött célok elérésében ragadhatók meg:

- Rossz beidegződések leküzdése.

- Nézetek, hitek terén a kognitív váltás elősegítése.

- Elmélet és gyakorlat közötti híd megteremtése.

- A tanári kreativitás fejlődése.

- A reflektivitás erősödése.

- Gyakorlottság szerzése a team-munkában.

Összességében tehát bíztató képzési eredményekről adhatunk számot, az elkötelezett, jól motivált hallgatóság nagy lépéseket tett az inkluzív gondolkodás és az e szellemben végzett pedagógiai tevékenység megvalósításának útján.

\section{Irodalom}

Falus Iván (2010): A pedagógusképzés korszerüsítése-európai tendenciák Pedagógusképzés, 1. sz. 19-36.

Falus Iván (2010): Feszültségek - dilemmák - megoldások a bolognai-rendszerủ tanárképzéssel kapcsolatban. Pedagógusképzés, 1. sz. 133-138.

Falus Iván - Kotschy Beáta (2006): Kompetencia alapú tanárképzés: Divatos jelszó vagy a megújulás eszköze. Pedagógusképzés, 3-4. sz. 67-75.

Gaskó Krisztina - Kálmán Orsolya (2010): A pedagógia szakos hallgatók tanulása és a képzésük. Tanulási sajátosságok vizsgálata a BaBe kutatás keretében. Poszter bemutató, ELTE PPK, Budapest.

Hunyady György (2010): Kurta hívószavak egy átmeneti helyzetben: a csőd, a minőség, a szak és az ár. Pedagógusképzés, 1. sz. 73-76.

Oláh Attila (2005): Érzelmek, megküzdés és optimális élmény. Belső világunk megismerésének módszerei. Trefort Kiadó, Budapest.

Pléh Csaba (2006): A tanulás tanulása és az egész életen át tanulás a pszichológus szemével. Pedagógusképzés, 3-4. sz. 5-19.

Rapos Nóra (2011): A szakmai professzionalizmusra alapozott képzés, pedagógia tárgyak a tanári modulban. In: Baumstark Bea - Gombocz Orsolya - Hunyady György: A tanárképzés 2010-2011 fordulóján. Piliscsabai regionális tanácskozás. ELTE Eötvös Kiadó, Budapest, 113-129.

Réthy Endréné (2003): Motiváció. Tanulás. Tanitás. Miért tanulunk jól vagy rosszul? Nemzeti Tankönyvkiadó, Budapest.

Réthy Endréné (2007): Integráció, inkluzió Európában. In: Bábosik István - Torgyik Judit (szerk.): Pedagógusmesterség az Európai Unióban. Eötvös József Könyvkiadó, Budapest, 217-234. 
Réthy Endréné (2006): Pedagógusok tanításra irányuló vélekedései, nézetei és azok befolyásolási lehetőségei. In: Bábosik István (szerk.): Az iskola optimalizálása a struktúra változtatása nélkül. PEM az URBIS Kiadó közremüködésével Budapest, 143-168.

Réthy Endréné, Schaffhauser Franz, Schiffer Csilla (2006): Az EUMIE mesterfokú tantervinkluzív nevelés szakon. Pedagógusképzés, 1-2. sz. 93-99.

Réthy Endréné (2009): Tanulói vélekedések az iskoláról. Az iskola mint örömforrás. In: Szabolcs Éva (szerk.): Ifjúkorok, gyermekvilágok. Eötvös József Könyvkiadó, Budapest, 11-44.

Réthy Endréné (2011): Tanári teljesitmény-visszajelzés hatása a tanulók személyiségére. Comenius Oktató és Kiadó Kft., Pécs.

Rethy, M. (2010): Das neue allgemeine pädagogische Konzept. Integration in Ungarn Zeitschrift für Inklusion. Online net Nr.2. www.inklusion-online.net/index.pkp/inklusion

Vermunt, J. D. (1994): Invertory of Learning Styles in Higher Education. Tilburg University, Department of Educational Psychology, Tilburg. 